Marx, R. \& Dyckerhoff, H. (1943). Klin. Wschr. 22, 570.

Montigel, C. \& Pulver, R. (1952). Congr. int. Biochim. II. Paris. Résumés des Communications, p. 220. Moore, T. \& Wang, Y. L. (1945). Biochem. F. 39, 222.

Owren, P. A. (1949). Scand. F. clin. Lab. Invest. I, 13 r.

Owren, P. A. (1951 $a)$. Rev. Hémat. 6, 135.

Owren, P. A. (195 $\mathrm{I} b)$. Scand. F. clin. Lab. Invest. 3, I68.

Owren, P. A. \& Aas, K. (195I). Scand. F. clin. Lab. Invest. 3, 201.

Owren, P. A. \& Bjerkelund, C. (1949). Scand. F. clin. Lab. Invest. r, I62.

Plum, P. (1949) Acta Paediat., Stockh., 38, 526.

Quick, A. J. \& Collentine, G. E. (1950). Ұ. Lab. clin. Invest. 36, 976.

Quick, A. J. \& Collectine, G. E. (195I). Amer. Physiol. 164, 7 I6.

Quick, A. J. \& Stefanini, M. (1948). F. biol. Chem. 175, 945.

Rodahl, K. (1949). Nature, Lond., 164, 531.

Rodahl, K. (1950). Skr. norsk. Polarinst. no. 95.

Rodahl, K. \& Moore, T. (1943). Biochem. F. 37, I66.

Sanford, H. N., Kosalik, M. \& Blackmore, B. (1949). Amer. F. Dis. Child. 78, 686.

Smith, C. C., Fradkin, R. \& Lackey, M. D. (1946). Proc. Soc. exp. Biol., N.Y., 6r, 398.

Smith, H. P., Warner, E. D. \& Brinkhous, K. M. (1937). F. $\operatorname{exp.~Med.~66,~801.~}$

Snelling, C. E. \& Nelson, W. (1943). F. Pediat. 22, 77.

Solvonuk, P. F., Jaques, L. B., Leddy, J. E. Trevoy, L. W. \& Spinks, J. W. T. (1952). Proc. Soc. exp. Biol., N.Y., 79, 597 .

Søndergaard, E. \& Dam, H. Acta. pharmacol. tox., Kbh. (To be published.)

Sørbye, Ø., Kruse, I. \& Dam, H. (I950a). Acta chem. scand. 4, 549.

Sørbye, Ø., Kruse, I. \& Dam, H. (1950b). Acta chem. scand. 4, 83 I.

Sørbye, Ø., Kruse, I. \& Dam, H. (1951). Acta chem. scand. 5, 487.

Sørbye, Ø., Kruse, I. \& Dam, H. (1952). Congr. int. Biochim. II. Paris. Résumés des Communications, p. 417 .

Spinks, J. W. T. \& Jaques, L. B. (1950). Nature, Lond., I66, I84.

Waddell, W. W. Jr. \& Lawson, G. M. (1940). F. Amer. med. Ass. I15, 1416.

Walker, S. E., Eylenburg, E. \& Moore, T. (x947). Biochem. F. 4r, 575.

Ware, A. G., Guest, N. N. \& Seegers, W. H. (1947). F. biol. Chem. 169, 23 I.

Watkin, D. M., Van Itallie, T. B., Logan, W. B., Geyer, R. P., Davidson, C. S. \& Stare, F. J. (I951). F. Lab. clin. Med. 37, 269 .

\title{
The Fat-soluble Vitamins in Metabolic Processes
}

\author{
By T. Moore, Dunn Nutritional Laboratory, \\ University of Cambridge and Medical Research Council
}

Even with Professor Dam (1953) undertaking the discussion of vitamin $\mathrm{K}$ it will be impossible for me to present a comprehensive and fully documented account of the role of the fat-soluble vitamins in metabolism in the short space at my disposal. The ground to be covered includes several popular and highly specialized fields of research, such as the role of vitamin $\mathrm{A}$ in dark adaptation, the influence of vitamin $D$ on calcification, and the action of vitamin $E$ as a biological antioxidant and as a protective agent against muscular dystrophy and liver injuries. Any of these topics could be made the subject of a substantial monograph, and a short review which must make reference to them all can be little more than a brief summary of some of the main facts and theories.

\section{Contrasts between vitamins $A, D$ and $E$}

Before our attention is turned to the individual vitamins, however, we may pause to recall the interesting differences in their modes of formation, transport and destruction in the body. Thus the animal is not able to synthesize provitamins A, 
but can readily convert them to the vitamin when they are supplied in the diet. Even if it is given as the free alcohol, vitamin $A$ is readily esterified, and predominates in this form in the tissues. In the blood the 'resting level' is contributed by the free alcohol, and any increase caused by dosing is held in the esterified form. Provitamin $\mathrm{D}$, on the other hand, can readily be synthesized by the animal in the form of 7 -dehydrocholesterol, but generally cannot be converted into the vitamin without the external stimulus of ultraviolet irradiation. Knowledge of the state of combination of vitamin $\mathrm{D}$ is sparse, but early experiments on the preparation of antirachitic concentrates from cod-liver oil suggested that it is less readily esterified than vitamin A. For vitamin $\mathrm{E}$ we have no evidence of the conversion of a provitamin into a vitamin, and even if artificial esters are administered, the vitamin is held in the tissues and blood in the free form.

When vitamin $A$ is given in large doses it may often be stored almost quantitatively in the livers of experimental animals, although sometimes it may partly be lost, or used up with undue rapidity. Both vitamins $D$ and $E$, which are much more stable than vitamin $\mathrm{A}$ in vitro, at least towards oxidation, are stored very much less efficiently, and are converted into unidentified products much more readily. The quantitative requirements also differ widely; the daily doses barely adequate for curing deficiency in the rat are about $0.025 \mu \mathrm{g}$ for vitamin $\mathrm{D}, 0.5 \mu \mathrm{g}$ for vitamin $\mathrm{A}$ and $50 \mu \mathrm{g}$ for vitamin $\mathrm{E}$.

\section{Vitamin $A$}

The rhodopsin cycle. The participation of vitamin A in metabolic processes has been studied most closely in the retina, and the detailed information now available is due mainly to the intensive studies of Wald and of Morton. The cycle consists of three phases. (I) During dark adaptation vitamin $\mathrm{A}$ and the special protein opsin combine together to form the red compound rhodopsin. Hubbard \& Wald (1952) have claimed that in order to react the vitamin A must be present as one of its less familiar cis isomers. (2) When the retina is exposed to light, rhodopsin first yields yellow intermediates, which vary in shade according to $\mathrm{pH}$. These transitory products are next transformed to the yellow pigment retinene, which has been identified by Ball, Goodwin \& Morton (r948) with vitamin A aldehyde, and the protein opsin. (3) Retinene is reduced back to vitamin A by the action of retinene reductase, an enzyme which is present in the outer limbs of the rods, acting in conjunction with reduced cozymase. In a subsidiary cycle the cozymase, having lost its hydrogen to the retinene, is reduced again by a system made up of fructose, diphosphate and a dehydrogenase. It is interesting, as Wald (I 949) points out, that the nicotinamide of cozymase should be concerned in the metabolism of vitamin $A$, which is known to be protected by tocopherol. Three vitamins are therefore concerned in the same system.

Mucus formation. In certain shrimps, in which Fisher, Kon \& Thompson (1952) have found over $90 \%$ of the body's contents of vitamin A in the eyes, the rhodopsin cycle may presumably be regarded as the vitamin's main field of metabolic activity. In mammals, however, the vitamin $A$ present in the retina makes up a very small 
fraction of the total contents of the body. No evidence is available on the formation of rhodopsin elsewhere than in the retina, and we must look for different metabolic activities in the rest of the body.

One of the most characteristic effects of vitamin A deficiency is seen in the xerosis, or drying up, of membranes. This phenomenon has been studied by Evans (1928) and others with particular reference to the vaginal epithelium of the rat, which may conveniently be examined by taking smears. In the normal animal the smear, except during oestrus, contains epithelial cells, leucocytes and mucus. The deficient animal, on the other hand, continually shows a smear suggestive of the late stages of oestrus, and made up entirely of thin rectangular, non-nucleated flakes of skin or horn. The final result of the metabolic activities of vitamin A, therefore, is to stimulate the formation of soluble mucoproteins and to depress the formation of proteins of the insoluble type typified by keratin (Mason \& Ellison, 1935). By definition the mucoproteins contain about $4 \%$ of acetylglucosamine, or some other amino-derivative of a sugar. It appears, therefore, that the vitamin either directly or indirectly stimulates the synthesis of amino-derivates of sugar, or directs their combination into protein molecules. At any rate it is clear that the secretion of such substances by the vaginal epithelium is checked if the vitamin is withheld.

Vitamin $A$ and sex. There are many indications of interrelations between vitamin $\mathrm{A}$ and the sex hormones, particularly oestrogens (Moore, Sharman \& Ward, 1952a). The livers of male rats tend to contain less vitamin A than those of females, but the kidneys and blood contain more. In human beings night-blindness has been reported to be much more common in men than in women. Men's blood tends to contain a higher resting level of vitamin A than women's, and also shows higher peak values after heavy dosing. Women's blood tends to be higher than men's in carotenoids.

For evidence that the interaction of vitamin $\mathrm{A}$ and the oestrogens may amount to more than a casual overlapping of their spheres of influence we may turn to experiments in which the balance between these factors has been artificially disturbed. In rats deficient in vitamin A removal of the ovaries does not prevent the vaginal smear from becoming keratinized, but when the vitamin is given to ovariectomized animals the periodical keratinization during oestrus is avoided. Heavy dosing with oestrogen, even in animals given adequate doses of vitamin A, will induce long periods of keratinization. Conversely Hohlweg (195I) has found that the smears of animals that have been made continuously keratined by moderate doses of oestrogen may be converted to the mucous type by massive doses of vitamin A.

Vitamin $A$ and protein. Meunier, Ferrando, Jouanneteau \& Thomas (1949) have found that the toxicity of sodium benzoate in rats may be reduced either by giving glycine or by raising the vitamin A allowance above the marginal level. They concluded that vitamin A is concerned in protein metabolism. Moore, Sharman $\&$ Ward (1952b) have tested the value of raised allowances of vitamin A in enabling rats to maintain their weight on a diet low in protein. Rats with generous allowances certainly maintained their weights somewhat better than rats given marginal allowances. It is still doubtful, however, whether the beneficial action of the vitamin 
extends beyond a general principle that two superimposed partial deficiencies may have more severe effects than either deficiency by itself.

\section{Vitamin D}

Our knowledge of the role of vitamin $\mathrm{D}$ in metabolism is fairly adequate in regard to the final results which it produces, but the primary point of its biochemical action remains obscure. Some years ago Harris (1932) suggested the essential effect of this vitamin is to increase the level of calcium and phosphorus in the blood, either by increasing their net absorption from the intestines or by effecting their mobilization from bones that have already been formed. By this mechanism these elements are kept at their proper levels in the blood, and calcification of the developing bones takes place without the further intervention of the vitamin. Apparently Nicolaysen $(1937 a, b)$ held much the same view, but with emphasis on the point that vitamin $\mathrm{D}$ may only directly influence the absorption of calcium, leaving the absorption of phosphorus to adjust itself as a secondary effect. Later, various complicating factors were recognized. Thus phytic acid, which is a phosphorylated derivative of the 'vitamin' inositol, inhibits the efficient absorption of calcium. Lactose, citric acid and the fatty acids of butter may in suitable circumstances aid calcification. Certain unusual forms of rickets and osteomalacia only respond to vitamin $\mathrm{D}$ when it is given in massive doses.

Experiments with labelled calcium and phosphorus have been made by many workers, and as the result of such studies Cohn \& Greenberg (1939) have inferred that vitamin $\mathrm{D}$ aids the transference of organic to inorganic phosphorus. Harrison \& Harrison (195I), however, have advised caution before this conclusion is accepted in view of the rapidity with which calcium can be exchanged between the bones and the blood.

In rickets the level of alkaline phosphatase in the blood is greatly increased; presumably it comes from the large masses of cartilaginous tissues awaiting calcification. Zetterström \& Ljunggren (I95I) have suggested that vitamin D may stimulate the action of this enzyme, and have demonstrated that in vitro a water-soluble phosphorylated form of vitamin $D$ can increase the activity of phosphatases prepared from bone, kidney or intestines. If this finding can be accepted, it indicates that the active vitamin $D$ is not restricted to the absorption of calcium and phosphorous and their mobilization into the blood, but extends to a direct influence on the cells undergoing calcification. Further support for this view might be found in experiments by Barnicot (1948) on the implantation of fragments of mouse bones into the cerebral hemispheres of other mice. Thus when crystals of calciferol were attached to the implanted bone, a form of osteoporosis developed which was held to be similar to the injury caused by massive doses of the vitamin when given orally.

Zetterström \& Ljunggren's experiments may be criticized, however, on the grounds that no natural phosphate of calciferol is known to exist, and in Barnicot's work the concentration of vitamin used was far beyond the normal biological range. In spite of the patient work of numerous investigators during the past quarter of a century the field provides ample scope for further studies. 


\section{Vitamin $E$}

The tocopherols, but not their esters, act as antioxidants in protecting fats. When their protective powers are studied in vitro, they are usually found to be less effective than simpler molecules, such as hydroquinone, but they are distinguished by their ability to pass into the tissues of animals, and to act there as 'biological antioxidants '.

The protection of lipids. The pathological and biochemical lesions in vitamin $\mathrm{E}$ deficiency are many and various, but the abnormalities in lipid metabolism may be mentioned first as being directly related to the antioxidative power of the vitamin as demonstrated in vitro. Granados \& Dam (1945) have shown that signs of abnormal fat metabolism may readily be seen by the naked eye in rats that have been given diets free from tocopherols and containing a high proportion of cod-liver oil. The fat deposits have a brown discoloration and peroxides can usually be detected by chemical tests. The same discoloration has also been reported in chickens, pigs and minks.

The brown pigment appears to be formed from the more highly unsaturated acids of the cod-liver oil by oxidation and polymerization. Other highly unsaturated acids, such as those of linseed oil, may also cause discoloration. The brown pigment is probably similar to 'ceroid' as produced in certain forms of experimental liver disease. Its formation does not run at all parallel, however, to the brown discoloration of the rat's uterus which occurs in vitamin $E$ deficiency uncomplicated by the administration of cod-liver oil.

As a converse to the ability of vitamin $E$ to protect the unsaturated acids of codliver oil against oxidation, it has been amply proved that cod-liver oil inactivates vitamin $\mathrm{E}$ when given simultaneously to rats. Cod-liver oil may also precipitate the symptoms of vitamin E deficiency in calves (Blaxter, Watts \& Wood, 1952).

Vitamin E also protects vitamin A, both in the tissues (Davies \& Moore, I94I) and in the intestinal tract (Hickman, Harris \& Woodside, 1942). The utilization of carotene is increased by small doses of tocopherol, but decreased by massive doses.

Muscle metabolism and enzyme systems. Long before the role of vitamin $\mathrm{E}$ in preventing 'nutritional muscular dystrophy' was recognized, Goettsch \& Brown (r932) demonstrated that the creatine content of the dystrophic skeletal muscles of rabbits was greatly reduced. Soon afterwards Victor (1934) found that the oxygen uptake of these tissues was much increased. Later work confirmed these findings in various animals, and demonstrated that the abnormalities could be prevented by giving tocopherol. According to Melville \& Hummel (I95I) the effects of vitamin $\mathrm{E}$ deficiency may be detected in rabbits by biochemical estimations before paralysis develops. Creatine falls in the muscles and increases in the urine, liver and kidneys.

Numerous studies on enzyme systems have followed, but have so far failed to give a clear explanation of the raised oxygen uptake of the deficient tissues. In rabbits 
in the early stages of deficiency Jacobi, Rosenblatt, Wilder \& Morgulis (1950) have found no changes in malic dehydrogenase, cytochrome oxidase, succinic dehydrogenase, lactic dehydrogenase, fumarase, adenosinetriphosphatase and uricase. In deficient rats Kalsbeek \& van der Meer (1950), however, estimated that liver esterase was only $64 \%$ of normal. Carey \& Dziewiatkowski (r949) have reported that acid phosphatase is doubled in rabbits. According to Barber, Basinski \& Mattill (1949) aspartic-glutamic transaminase is about halved in deficient rabbits and guinea-pigs.

Experiments on the effect of adding the vitamin to enzyme systems have usually been made with the artificial phosphate ester, which inhibits most enzyme systems. Unfortunately its action may be often explained by its detergent properties and by its effect on calcium, but some evidence remains to suggest that the vitamin inhibits succinoxidase (Jacobi, Rosenblatt, Chappell \& Morgulis, 1950) and hyaluronidase (Miller \& Dessert, 1949) otherwise than as a detergent. Early experiments by Hove (1943) on the effect of tocopherol in inhibiting lipoxidases in the coupled oxidation of methyl linolate and carotene must also be remembered.

Interrelations with protein. Dam (I944) first reported that rats given diets severely deficient in protein survived longer when they were dosed with vitamin $\mathrm{E}$ than when this vitamin was withheld. Other workers found that with allowances of protein adequate for survival, but insufficient for normal growth, the rates of growth were more rapid in animals dosed with tocopherol than in others which were not dosed (Hove \& Harris, 1947; Moore, 1949). Approaching the problem from another angle Schwarz (1944) reported that tocopherol protected rats deficient in protein from liver disease, and. György (1947) and Himsworth \& Lindan (1949) confirmed and extended the finding. A complicated story has since developed, but as the central theme it has been established that severe protein deficiency causes death by massive necrosis of the liver, which may be averted by giving either cystine or tocopherol. Excess of cystine, on the other hand, causes a tendency to cirrhosis of the liver, with deposition of ceroid pigment; vitamin $\mathrm{E}$ can apparently only delay the appearance of these injuries. Moore \& Wang (r947) have suggested that the brown pigment which occurs in the muscle cells of rats deficient in vitamin E may be derived from protein. Histologically it closely resembles the pigment seen in brown atrophy of the human heart.

Other metabolic abnormalities. György \& Rose (1949) found that the red blood cells of rats deficient in vitamin $\mathrm{E}$ may readily be haemolysed by dialuric acid. Moore (1942) found that deficiency of vitamin $E$ in the same animal causes a loss of the brown colour of the incisor teeth, as previously reported in deficiency of vitamin A. Deprivation of vitamin $\mathrm{E}$ bleaches the teeth much more readily in albino rats than in piebalds. Dam, Granados \& Maltesen (1950) have drawn attention to the high iron content of the brown pigment. They report that in teeth that have been depigmented by deficiency of vitamin $\mathrm{E}$ the decrease in iron is accompanied by a rise in manganese.

Vitamin $E$ substitutes. In a series of interesting papers Dam and his colleagues have claimed that a number of substances with ' redox ' properties, and particularly 
methylene blue, are able to cure or prevent many of the lesions typical of vitamin E deficiency. Thus according to Dam \& Granados (1952) the dyestuff could even replace tocopherol in promoting reproduction in rats. In tests with methylene blue Moore (1952), with Sharman \& Ward, has been unsuccessful in preventing either resorption of the foetuses or degeneration of the testes in rats deficient in vitamin $\mathrm{E}$. In confirmation of the Danish work, however, the dye was found to resemble vitamin $\mathrm{E}$ in increasing the storage of vitamin $\mathrm{A}$ in the liver. It was also completely effective in preventing brown discoloration of the uterus and injury to the kidney tubules, which were not included among the injuries investigated by Dam.

As a first suggestion for explaining the potency of methylene blue it might be assumed that the dye can protect tocopherol, and so allow the stores available in the body to suffice for a longer period. This assumption is probably correct, but it does not seem to allow a full explanation of the ability of the dye to prevent some abnormalities but not others. In rats given a diet deficient in vitamin $\mathrm{E}$ with supplements of methylene blue the uteruses remain normal in colour for a least 9 months, but when similarly treated animals are mated after 5 months they resorb their foetuses. This disparity might be explained, of course, if less vitamin $E$ were required to maintain the normal colour of the uterus than to prevent resorptions. The evidence at present available, however, gives no justification for this view.

It appears therefore that methylene blue, which presumably enters the tissues in its leuco form, can itself take over some of the functions of the tocopherols. As a working hypothesis we may perhaps consider the dye as being unable to replace the vitamin in its primary functions, but as being effective in preventing the accumulation of secondary products, such as the peroxides of fat and the brown pigments of the fat deposits and uterus. By conversion to the blue form the leuco compound could accept oxygen from peroxides, and could readily be returned to the leuco form by the enzyme systems of the tissues. Another profitable field is obviously opening up for collaboration between nutritionists and enzyme biochemists.

\section{REFERENCES}

Ball, S., Goodwin, T. W. \& Morton, R. A. (1948). Biochem. F. 42, 516.

Barber, M. A., Basinski, D. H. \& Mattill, H. A. (1949). F. biol. Chem. r8r, I7.

Barnicot, N. A. (1948). Nature, Lond., 162, 848.

Blaxter, K. L., Watts, P. S. \& Wood, W. A. (1952). Brit. F. Nutr. 6, 125.

Carey, M. M. \& Dziewiatkowski, D. D. (1949). F. biol. Chem. 179, I I9.

Cohn, W. E. \& Greenberg, D. M. (1939). F. biol. Chem. r30, 625.

Dam, H. (1944). Proc. Soc. exp. Biol., N.Y., 55, 55.

Dam, H. (1953). Proc. Nutr. Soc. 12, Ir4.

Dam, H. \& Granados, H. (I952). Acta pharmacol. tox., Kbh., 8, 47.

Dam, H., Granados, H. \& Maltesen, L. (1950). Acta physiol. scand. 21, 124.

Davies, A. W. \& Moore, T. (194I). Nature, Lond., 147, 794.

Evans, H. M. (1928). 7. biol. Chem. 77, 651.

Fisher, L. R., Kon, S. K. \& Thompson, S. Y. (1952). F. Mar. biol. Ass. U.K. 31, 229.

Goettsch, M. \& Brown, E. F. (r932). F. biol. Chem. 97, 549.

Granados, H. \& Dam, H. (1945). Acta. physiol. scand. 1o, 163.

György, P. (1947). Report of the Sixth Conference on Liver Injury, p. 67. New York: Josiah Macy Jr. Foundation.

György. P. \& Rose, C. S. (1949). Ann. N.Y. Acad. Sci. 52, 231. 
Harris, L. J. (1932). Lancet, 222, 103 ז.

Harrison, H. E. \& Harrison, H. C. (1951). F. biol. Chem. 188, 83 .

Hickman, K. C. D., Harris, P. L. \& Woodside, M. R. (1942). Nature, Lond., I50, 9 I.

Himsworth, H. P. \& Lindan, O. (r949). Nature, Lond., 163, 30.

Hohlweg, W. (1951). Klin. Wschr. 29, 193.

Hove, E. L. (1943). Science, 98, 433.

Hove, E. L. \& Harris, P. L. (1947). F. Nutr. 34, 57 I.

Hubbard, R. \& Wald, G. (1952). Congr. int. Biochim. Ir. Paris. Résumés des Communications, p. 213. Jacobi, H. P., Rosenblatt, S., Chappell, J. W. \& Morgulis, S. (1950). Arch. Biochem. 27, 9.

Jacobi, H. P., Rosenblatt, S., Wilder, V. M. \& Morgulis, S. (1950). Arch. Biochem. $27,19$.

Kalsbeek, F. \& van der Meer, C. (1950). Biochim. biophys. Acta 6, 135.

Mason, K. E. \& Ellison, E. T. (1935). F. Nutr. 9, 735.

Melville, R. S. \& Hummel, J. P. (195 r). F. biol. Chem. I9r, $3^{8} 3$.

Meunier, P., Ferrando, R., Jouanneteau, J. \& Thomas, G. (1949). Bull. Soc. Chim. biol., Paris, 31, I4I3.

Miller, W. H. \& Dessert, A. M. (1949). Ann. N.Y. Acad. Sci. 52, 167.

Moore, T. (1942). Biochem. F. 37, I12.

Moore, T. (1949). Ann. N.Y. Acad. Sci. 52, 206.

Moore, T. (1952). Experientia. (To be published, 1953.)

Moore, T., Sharman, I. M. \& Ward, R. J. (1952a). Congr. int. Biochim. Ir. Paris. Résumés des Communications, $p .220$.

Moore, T., Sharman, I. M. \& Ward, R. J. (1952b). Biochem. $\mathcal{7 . ~ 5 2 , ~ x i i . ~}$

Moore, T. \& Wang, Y. L. (1947). Brit. F. Nutr. I, 53.

Nicolaysen, R. (r937a). Biochem. F. 31, ro7.

Nicolaysen, R. (1937b). Biochem. F. 31, 122.

Schwarz, K. (1944). Hoppe-Seyl. Z. 281, rog.

Victor, J. (1934). Amer. Ұ. Physiol. 108, 229.

Wald, G. (1949). Science, 109, 482.

Zetterström, R. \& Ljunggren, M. (1951). Acta chem. scand. 5, 283.

\title{
The Mode of Action of Vitamin C
}

\author{
By Leslie J. Harris, Dunn Nutritional Laboratory, \\ University of Cambridge and Medical Research Council
}

I have a relatively easy task compared with the other contributors to this discussion, because there is less that can be said definitely about the mode of action of vitamin C. For some other water-soluble vitamins, such as vitamin $B_{6}$ and pantothenic acid, we can speak of specific coenzyme systems, each with its own clear biochemical role to play. But for vitamin $\mathrm{C}$ we have not yet reached this stage of knowledge. Indeed, in my view, the two most essential facts about vitamin $\mathrm{C}$ action, so far as present knowledge goes can be summed up under a couple of simple headings, as follows:

(a) Biochemical role of vitamin C. It is generally thought that the action of vitamin $\mathrm{C}$ must be linked in some way with its intense reducing action, which depends on the presence in its molecule of the characteristic ene-diol grouping. However, it has to be admitted that the exact biochemical role is still obscure. One of the few definitely established facts so far is that, in animal tissues, ascorbic acid can catalyse the oxidation of the aromatic amino-acid, tyrosine.

(b) Interpretation of the morphological effects of deficiency. The structural changes which can be seen microscopically in scurvy, for example in the teeth and 